\title{
Fish Is a Fighting Food: North American Canned Salmon and the First World War
}

\author{
Ross Coen \\ University of Washington
}

\begin{abstract}
During the First World War, the Pacific Northwest canned salmon industry, which was headquartered and operated in Alaska, British Columbia, Washington, and Oregon, sent millions of cases of its product to Britain and France for consumption by Allied troops and civilians. The war transformed the canned salmon industry in ways that reverberated long after the 1918 armistice. In order to meet the ever growing demand for fish, the industry expanded dramatically, almost doubling overnight in some regions, which led to overfishing, depleted fish stocks, and concomitant government regulation of fisheries that would only increase over time. In addition, the high rates of product spoilage-a direct result of new and disreputable packing companies entering the market in hopes of securing guaranteed government contracts-led to greater enforcement of pure food laws and safety regulations, an action that in turn educated the public about sanitation and the emerging science of nutrition. The adoption of canned salmon as a wartime ration may in hindsight seem obvious, yet the process was by no means inevitable but rather required industry lobbying and negotiations with the United States and Canadian governments over prices, delivery procedures, and general fishing operations. This article examines the complex and occasionally contradictory process of bringing Pacific Northwest canned salmon to Europe during the First World War. This article is part of a special collection of papers originally presented at a conference on "The North and the First World War," held May 2016 in Whitehorse, Yukon.
\end{abstract}

The Northern Review 44 (2017): 457-464 
From 1914 to 1918, the Pacific Northwest canned salmon industry, which was headquartered and operated in Alaska, British Columbia, Washington, and Oregon, sent millions of cases of its product to Britain and France for consumption by Allied troops and civilians. The supply was badly needed considering the difficulties in procuring other sources of meat amid the chaos in Europe during the Great War. In this way, canned salmon played a small but important role in the war.

The reverse was even more profound, as the First World War transformed the Pacific Northwest canned salmon industry in ways that reverberated long after the 1918 armistice. In order to meet the ever growing demand for fish, the industry expanded dramatically, almost overnight and doubling in size in some regions, which upended local economies and led to overfishing that depleted fish stocks throughout the North Pacific. The governments of the United States and Canada, which had, to different degrees, limited involvement in fisheries management prior to the war, assumed greater regulatory authority for both cannery operations and maintaining the health and long-term viability of fish stocks. In addition, the disreputable operations and inferior product of many of the market's new entrants (i.e., those who sought to profit from guaranteed wartime contracts) spurred government inspectors to begin enforcing safety and sanitary regulations, a move welcomed by the more established salmon packers. ${ }^{1}$

Although the adoption of canned salmon as a military ration may in hindsight seem to be an obvious move for US and Canadian authorities, there was nothing inevitable about it. In fact, the process was by no means smooth, and it required industry lobbying, cajoling, and even gimmicks. This paper examines the complex and occasionally contradictory process of bringing Pacific Northwest salmon to Europe, and attempts to add texture and context to what may intuitively seem like a straightforward history.

In August 1914, within weeks of the start of the war, salmon packers openly expressed delight at the commercial prospects. According to Pacific Fisherman, a trade publication based in Seattle, "The dawn of a brighter days [sic] seems to be breaking for the salmon canners of this coast, and ... it is due to war." 2 The industry was not prepared to respond immediately, however. Neither the packers nor the brokers (the wholesaler, or the middleman between the packers and the retailer) kept excess stock on hand as a matter of course. Cases of salmon sitting in warehouses incurred a hefty expense and was not done at the time. But in the months after the 
outbreak of war, calls began flooding in to every packer from brokers eager to boost their stocks. The packers hesitated before expanding operations, however, because of the uncertainties regarding cost and availability of materials such as tin plate, solder, rope, twine, and every other good that was likely to be in short supply now that Europe was embroiled in war. Despite this uncertainty, packers throughout the Pacific Northwest undertook plans to expand operations.

The British Columbia provincial government announced its capacity and willingness to supply product to Europe in October 1914, with the gift of 25,000 cases of canned salmon (forty-eight one-pound cans per case) to British armies. The shipment represented not only a patriotic gesture, but also a savvy marketing ploy. The British export market at this time consisted almost entirely of red salmon, a high-grade product valued for its firm flesh and high oil content. But the wartime gift consisted entirely of pink salmon, one of the lower, cheaper grades of fish. According to a BC trade official, "This gift will ultimately prove of great value to the industry, as it will place pink salmon in the hands of many persons who never had seen it before, and after this distressing war is over its wholesomeness will be better and more widely appreciated in England than it is today." ${ }^{3}$

Two years into the war, however, BC salmon (or fish in general for that matter) had not been fully integrated to European wartime markets. One observer surmised that the British War Office likely hadn't updated its ration list since the Crimean War. This would change due in part to the work of Major Hughie Green, a Scotsman from Glasgow who joined Canadian Forces from his home in Saskatoon, where he had worked as a fish broker. While stationed in Quebec, Green facilitated the acquisition of fish for the mess, eventually getting it placed in the commissaries and on the menu twice per week for troops in training. In a story that is likely apocryphal to some degree, Major Green's actions caught the attention of Sir Samuel Hughes, Canadian Defence Minister, who appointed Green "fish-monger general of the forces" and charged him with getting Canadian fish on Britain's rations list. It was said that Major Green, in every meeting he had in London, carried a frozen whitefish under his arm, which by the end of the day was no longer frozen, and he resolved to keep up the gimmick until all Allied soldiers were eating fish or the halls of the war office reeked of the odor, whichever came first. ${ }^{4}$

For all his antics, Green actually had a valid sales pitch. The 1910s were a time of emerging knowledge of nutrition, protein, calcium, vitamins, iodine, and so on, and the major continually emphasized the nutritional content of salmon. By 1917, just one year after Green began his campaign, 
the British government was requisitioning up to $100 \%$ of certain grades of BC salmon.

American salmon packers also sought to expand their business. In November 1914, a consortium of canners published, "Canned Salmon, the Ideal Army and Navy Ration," a pamphlet they distributed to American consuls as well as armies and navies of dozens of nations not just in Europe but all over the world. Not surprisingly, Britain was identified as the most promising for market expansion not merely due to its present wartime needs but also because prior to the war the English were regular consumers of North American canned salmon. Up to $90 \%$ of all exports went to Britain alone: 18 million pounds in 1900, and by 1910 it had increased to nearly double that figure, 35 million pounds. There was no tariff on canned salmon imported to Britain, unlike in prewar France and Germany where high tariffs made American salmon so expensive as to be a luxury good. ${ }^{5}$

The pamphlet aroused little interest among nations in war-torn Europe. The American consul in Antwerp dryly informed the packers, "I regret to inform you that there is absolutely no chance of doing business with Belgium at the present time. Conditions are such that it is almost impossible to communicate, and totally impossible to ship any goods." ${ }^{\prime 6}$

The American packers did not limit their outreach to the Allies. In November 1914, well before the United States entered the war and at a time when it was still believed the conflict might be wrapped up quickly, they sent the pamphlet to the German army via the American consul in Breslau, who responded directly but in a measured, diplomatic tone: "Regarding the introduction of your salmon for [the German military], I beg leave to submit a few obstacles. ... In the first place, canned salmon ... for the [German] army and navy are considered as contraband of war by the countries now at war with Germany. In the second place, any assistance which will tend to facilitate trade in articles which have been declared to be contraband ... has been disapproved by the US government.."7 AustriaHungary likewise refused the entreaty. The US companies surely knew they'd be unlikely to place salmon as a military ration in the Central Powers, and their correspondence suggests they were merely looking ahead to opening postwar markets in these nations.

While promoting its product abroad, theindustry also began expanding its production capacity at home. In British Columbia, canneries were licensed by the province, and the number and location was regulated. The number of boats and types of gear were also strictly regulated. This worked to the advantage of the British Columbia Packers Association, a corporate conglomerate of several canneries that in the year of its formation in 1902 
produced $45 \%$ of the total pack. The BC government issued just eight new licences, all to new entrants, during the war. While the number of canneries went up by just $10 \%$, the total pounds of salmon produced went up by $42 \%$. The Hell's Gate rockslide of 1914, which decimated the red salmon runs in the Fraser River, both forced this expansion into new areas of Northern BC and resulted in greater harvest of pinks and chums, two of the lowest grades but the most plentiful salmon species. The new entrants and the British Columbia Packers Association's loss of its heretofore valuable Fraser River fisheries all contributed to the association's loss of market share from $45 \%$ in 1902 to just $16 \%$ two decades later. Total salmon production in the province increased from 36.6 million pounds in 1910, to 54.4 million pounds in 1915 , and again to 77.6 million pounds in $1918 .^{8}$

While the expansion of fisheries in $\mathrm{BC}$ occurred in a more or less orderly fashion due to the province's cannery licensing requirements, Alaska fisheries expanded in a much more ad hoc manner. New canneries in Alaska needed no licence from either the territorial or federal government, although regulators could issue restrictions on locations of canneries, number of lines of processing and canning machinery, and a few other factors. But all of Alaska was designated an open-access fishery, meaning anyone with legal gear could participate. The wide open nature of the fishery was reflected in fishery statistics during the war. Total salmon production shot up from 298 million pounds in 1910, to 411 million pounds just five years later, and again to 486 million pounds in 1917. The number of canneries in these years more than doubled from 54 in 1910, to 121 in 1918.

The war had a not unsubstantial influence on the social history of the fisheries as well. Canada's Department of Indian Affairs succeeded in getting some fishing and boat licences for Indigenous fishermen, but by and large, new licences during the war went to Whites in the interest of encouraging a "desirable class" of settlers in Northern BC. Japanese fishermen were entirely excluded. ${ }^{9}$ In Alaska, a proposal to lift restrictions on immigration of Chinese and Japanese so that they might work in canneries and help solve the labour shortage affecting the industry was sternly rebuked by Miller Freeman, a staunch advocate for the industry and publisher of Pacific Fisherman. According to Freeman, "It would be folly to think that such hordes of Orientals brought in now could readily be sent home with the passing of the emergency, or that the immigration once started, could easily be stopped. The people of the Orient are not lacking in enterprise. Their coming would be followed in a few years by commercial equality; in a generation by political and social equality, with the gradual crowding out of white blood."10 
Women entered the workforce to alleviate the labour shortage. The Seattle Can Company, for example, hired some fifty women in 1917, and canneries throughout the Pacific Northwest began employing Indigenous and non-Indigenous women for nearly all cannery jobs, including the operation of automated machinery. The roles of women in Pacific Northwest fisheries is a neglected topic that calls out for attention from historians.

By July 1917, the process of supplying canned salmon had become institutionalized in the US. In meetings between industry representatives and the Army and Navy, it was made clear that companies that obtained government contracts would be assured of "good business returns" and "reasonable profit," and that no confiscation or commandeering would take place. The Quartermaster-General would inform industry liaison E.B. Deming of Pacific American Fisheries of Bellingham, Washington, of the total amount the government wished to purchase, at which time each company would be invited to sell an amount directly proportional to the percentage it produced of the total annual pack. In other words, if a certain packer produced $10 \%$ of the total salmon pack, they would be eligible to sell up to $10 \%$ of the government's order. The contracts also specified that should the US military find it did not need the full quota of delivered product, the packers "will be expected to assist in relieving [the Army and Navy] of any excess quantities on hand."11

At the close of the meetings, E.B. Deming professed himself very pleased with the professionalism of the US military officials. He reported back to his colleagues that the government did not intend to disrupt normal commercial operations, nor did it plan on denying the industry a fair profit. All the packers, no matter the size, would have the opportunity to receive a quota and sell that amount. Companies remained free to pass on the opportunity as well, though Deming advised against it: "Under the present plan, nobody is to be compelled to sell for the Army and Navy, but all are given an opportunity to submit offers to the Government. The only compulsion is the fact that any packers who are able to offer their quota and fail to do so are going to be very decidedly 'in bad' with the rest of the trade, with the Government, and with the public at large."12

With the United States now in the war, patriotism had taken hold in the industry, and there would be no more pamphlets or sales offers going to Germany. Frank Wright, president of the Carlisle Packing Company, loaned the Olympic, his 65-foot yacht, to the Navy. And Kenneth Fowler, chief of the US Food Administration, addressed the Pacific Northwest fisheries with a rousing call: "Let your answer from now on be actionto every last man and every last unit of gear the same spirit of patriotic 
sacrifice which imbues our armies now fighting for the safety of all civilized firesides. We fully believe that the fishermen of the Pacific will respond as one man [and] will sound full speed ahead and keep all the spark-plugs sparking. Let the war slogan of the industry, 'Speed Up for Uncle Sam' be nailed to the mast-heads and sound along the Coast from the Gulf of California to Portlock Bank."13

In British Columbia, the same allowance was made for market share by each company, but it became a moot point by 1918 when the British Ministry of Food requisitioned $100 \%$ of certain grades of salmon. That is, it purchased all that could be produced. (For the sake of comparison, the US government purchased no more than $60 \%$ of the total pack in any year during the war.) The agreement stipulated a provisional price (i.e., $\$ 11$ per case of sockeye), which was different from the US rules that only stated a "fair" price would be determined later. In addition, payment to BC companies was made "on presentation and delivery of bill of lading [or] warehouse receipt," while in the US no direct provision for when payment would be made appeared in the contracts. In fact, this became a bone of contention with some Alaska packers when they had to warehouse, without payment, the quota of the pack that the government pledged to purchase.

At the end of the war, Ottawa and Washington, DC, returned all unused stock to the canned salmon companies, much of which had never left local warehouses to begin with. With the industry now sitting on millions of pounds of salmon, it initiated a marketing campaign designed to boost consumption both domestically and in the global export market. According to one optimistic industry executive, "[M]en of the Allied armies who have eaten canned salmon as a ration have scattered to their homes throughout the world [and] they will want more. Civilian families all over Europe, who have learned to eat canned salmon when other food was scarce, will want more."14 The industry's marketing campaign relied heavily on the emerging science of nutrition-just as did Major Hughie Green's wartime lobbying efforts - and canners readily assumed the task of educating consumers on the health benefits of salmon. The more established companies also welcomed the government-mandated sanitary inspections begun in the face of disreputable canners that had high rates of leaky and rusted cans, contaminated fish, and generally spoiled product. Inspections would not only shut down these fly-by-night operations, but would provide established packers with positive reports that could be used to assure consumers of the purity of their product. ${ }^{15}$

The war's other major impact to Pacific Northwest salmon fisheries involved government-led conservation efforts. Overfishing during 
the wartime boom was taken as a given, even if regulators knew so little about fish populations and spawning habits that it was virtually impossible to gauge both the short- and long-term effects of the rampant harvest. Nevertheless, both the United States and Canada enacted new domestic laws and over the next few decades would sign no fewer than three bilateral agreements on joint regulation of fisheries. Scientific investigations of Pacific fisheries also increased markedly as both nations sought to understand and thereby predict and manage the valuable salmon fisheries. ${ }^{16}$ In this way, the First World War not only changed the Pacific Northwest salmon fisheries during the war itself, but also exerted a profound influence that shaped the industry for decades to come.

\section{Author}

Ross Coen is a doctoral candidate in history at the University of Washington.

\section{Notes}

1. John N. Cobb, Pacific Salmon Fisheries, 3rd ed., Bureau of Fisheries Document No. 902 (Washington: Government Printing Office, 1921).

2. “War Boosts Canned Salmon," Pacific Fisherman, Aug 1914, 11.

3. “B.C. Gives Canned Salmon," Pacific Fisherman, Oct 1914, 13.

4. "Canadian National Fish Day Observed at Vancouver," Pacific Fisherman, Mar 1916, 13-16.

5. “Canned Salmon, the Ideal Army and Navy Ration," Pacific Fisherman, Apr 1915, 16-17.

6. Ibid., 17.

7. Ibid.

8. Diane Newell, ed., The Development of the Pacific Salmon-Canning Industry: A Grown Man's Game (Montreal: McGill-Queen's University Press, 1989), 157-63.

9. “Fisheries Investigation in British Columbia," Pacific Fisherman, Jul 1917, 33.

10. "Alien Fishermen," Pacific Fisherman, May 1917, 22.

11. “The Canning Industries Mobilized," Pacific Fisherman, Jul 1917, 11-13.

12. Ibid., 13.

13. “Fisheries Mobilization Plans Developed," Pacific Fisherman, Oct 1917, 11.

14. “Concerning Salmon Labels," Pacific Fisherman, Oct 1918, 32.

15. Ross Coen, "Selling Salmon to the World: The Export Market for Pacific Northwest Canned Salmon," Pacific Northwest Quarterly 105 (no. 1, Winter 2013/2014), 23-31.

16. Richard A. Cooley, Politics and Conservation: The Decline of the Alaska Salmon (New York: Harper, 1963); Joseph E. Taylor III, Making Salmon: An Environmental History of the Northwest Salmon Crisis (Seattle: University of Washington Press, 2001). 